\title{
Права человека и внутренняя компетенция государства
}

Шамсон P.T.*

Одной из общих тенденций современного мирового развития является усиление взаимозависимости государств, развитие их сотрудничества, интенсификация международных отношений. Это влечет за собой взаимодействие и сближение правовых систем, более того - их взаимопроникновение, развитие в одних системах элементов, которые являются ведушими в других. Происходит и совершенствование механизма реализации норм международного права как на мировом, так и на национальном уровне, без чего невозможно нормальное функционирование, как того так и другого.

Взаимосвязь государств требует, чтобы национально-правовые системы государства были совместимы как друг с другом, так и с системой международного права.

Кроме того, сегодня идет процесс становления права международного сообщества, отличительной чертой которого является повышенное внимание к обеспечению интересов международного сообщества в целом. Национальные интересы государств прочно связаны с интересами международного сообщества. Отныне даже могучая держава не в состоянии в одиночку, без сотрудничества с другими государствами защишать национальные интересы ${ }^{1}$.

Экономическое развитие той или иной страны сегодня напрямую зависит от степени ее интегрированности в мировую экономическую систему. Интеграция того или иного государства в международное сообщество предполагает необходимость приведения его права в соответствие с международными стандартами, прежде всего в области прав человека ${ }^{2}$.

\footnotetext{
- Шамсон Рияд Таха - к.ю.н., докторант кафедры теории и истории государства и права РУДН.

'См.: Лукашук И.И. Внешняя политика России и международное право. М., 1997. С. 16.

' Муромцев Г.И. Соотношение международного и внутригосударственного права в свете Конституции Российской Федерации // Право и политика современной России. M., 1996. C. 127.
} 
Уважение прав человека и основных свобод стало содержанием одного из обшепризнанных принципов современного международного права, определяющих основы взаимоотношений государств ${ }^{3}$.

Уважение и соблюдение прав человека входит сегодня в число наиболее важных задач, необходимость решения которых стоит перед мировым сообшеством. Права человека являются универсальными и поэтому способствуют формированию единого гуманитарного правового пространства. Права человека - это права личности, следовательно, человек как участник общественных отношений имеет одинаковые, всеобщие права, независимо от того, в каком государстве, на какой территории он проживает.

Защита прав и свобод человека порождает в первую очередь отношения между государством и индивидом. Поэтому отношения в деле зашиты прав и свобод человека - это в основном внутригосударственные отношения, и обеспечиваются эти права и свободы посредством норм национального права, внутренних механизмов и процедур. Однако не все отношения в области обеспечения прав человека являются внутригосударственными. Когда речь идет о международной защите прав чёловека и международном сотрудничестве в этой области, то возникают проблемы правосубъектности индивида в международном и национальном праве, а также соотношения международного и внутригосударственного права, международных стандартов по правам человека и внутренней компетенции государства. Следует подчеркнуть, что решение этих вопросов зависит, с одной стороны, от общего уровня культуры, морали и динамики развития общественных отношений, как внутригосударственных, так и международных, с другой-от уровня развития международного права. Поэтому вопросы обеспечения прав человека, особенно сейчас, уже во многом не являются предметом суверенного усмотрения государств, эти вопросы могут рассматриватъся другими государствами и соответствующими международными организациями в рамках их компетенции на основе международного права.

Международно-правовая защита прав и свобод человека объективно обусловлена, она отражает динамическую и конструктивную связь между состоянием прав и свобод в отдельных странах и интересами других государств, состоянием международных отношений, международного мира и безопасности.

\footnotetext{
${ }^{3}$ Обеспечение прав и свобод человека в международном праве. М., 1987. С. 9; Международное право в современном мире. М., 1991. С. 109.
} 
Закрепленные международиым иравом принципы уважения прав и свобод человека представляют законный интерес для всех государств и не являются исключительно внутренним делом той или иной странь' .

Дело в том, что права и свободы человека определяются двумя уровнями социальных факторов - внутригосударственными и международными. Права и свободы как таковые могут существовать и развиваться в обществе и зависят от характера общественных отношений как внутри государств, так и на международной арене.

Проблема прав человека сложна и многопланова. Она имеет политические, экономические, социальные, юридические и другие аспекты. В различные эпохи проблема прав человека, неизменно оставаясь политико-правовой, приобретала религиозное, этическое либо философское звучание в зависимости от социальной позиции находящихся у власти социально-политических групп ${ }^{5}$. В различные исторические эпохи понятие, содержание и объем прав и свобод человека не были одинаковы.

Как известно, понятие прав человека вошло в правовую доктрину в эпоху буржуазных революций XVII-XVIII вв. Вопросы регулирования прав человека считались в то время внутренним делом каждого государства, а международное право не рассматривалось как инструмент соблюдения и защиты прав человека. Часто человек воспринимался в качестве не субъекта права, а объекта правоотношения.

Формирование международных стандартов в области прав и свобод человека начинается лишь с 1948 года. Это определяется следующими основными факторами.

a) В указанный период международное право стало обшим международным правом, выражающим интересы всего мирового сообщества. Именно в это время начался активный процесс разработки нового международного права, в котором участвовали все государства на основе принципа суверенного равенства, в том числе в какой-то мере значительная группа новых независимых государств, образовавшихся на месте бывших колоний. Сформировавшееся в период после второй мировой войны современное международное право исходит из учета интересов всех государств, создает правовую базу для развития нормальных отношений между государствами, в результате чего усиливается их сотрудничество.

\footnotetext{
${ }^{4}$ См.: Лукашук И.И. Внешняя политика России и международное право. М., 1997. С. 16.

5 Общая теория прав человека. «Гредисловие». М., 1996. С. IX.
} 
б) Происходит осознание той глубокой и тесной взаимосвязи, которая сушествует между положением личности, ее правами и свободами в отдельных государствах и состоянием международных отношений. Внутренняя политика подавления прав человека и основных свобод несет опасность не только народу данного государства, но и народам других стран. Такой вывод явился прямым результатом тяжелого опыта второй мировой войны, показавшего, что грубое и тотальное подавление политических, гражданских, социально-экономических и других прав и свобод в гитлеровской Германии и других фашистских государствах оказалось непременным предварительным условием навязывания ими агрессии против других государств ${ }^{6}$. «В Уставе $\mathrm{OOH}$, - писал австрийский юрист А. Федросс, - лежит идея, что государство, которое не предоставляет своим гражданам определенного минимума прав, всегда будет стремиться привить им агрессивную идеологию с тем, чтобы таким образом направить недовольство своих подданных на иностранные государства» ${ }^{7}$. Однако даже если антидемократические режимы не преследуют агрессивных целей в своей внешней политике, борьба против них внутри страны может создать проблемы региональной безопасности (Западный Пакистан в 1971 г., Либерия в 1990 г., Руанда в 1994 г.). Ярким примером преврашения прав человека в международную проблему являются межнациональные конфликты в Северной и Южной Осетии, Абхазии и, наконец, в Югославии.

в) Международной унификации института прав и свобод человека, развитию международного сотрудничества, направленного на содействие всеобщему уважению и соблюдению прав человека и основных свобод, способствовали создание и деятельность ООН как всеобщей международной организации по поддержанию мира и безопасности.

г) Страны мира становятся все более зависимыми друт от друта, происходящие внутри них процессы развития оказывают все большее влияние на международные отношения. С расширением связей между различными государствами и народами все сильнее стали сказываться на правах и свободах личности международные факторы. Опыт и идеи одних народов оказывают порой значительное воздействие на взгляды и практику в других странах. Постепенно стали складываться правила международной морали, а затем и юридические нормы, ставящие вне

${ }^{6}$ Обеспечение права и свобод человека в международном праве. М., 1987. С. 10; Международное право в современном мире. М., 1991.С. 109.

${ }^{7}$ См.: Международное право в современном мире. М., 1991. С. 110. 
закона наиболее грубые нарушения прав человека. Появились права и свободы, которые не должны зависеть ни от общественного строя данной страны, ни от других обстоятельств ${ }^{8}$.

Права человека стали объектом национального и международноправового регулирования. То, что в сфере международного права называется правами человека, становится правами граждан в сфере внутригосударственного права ${ }^{9}$. В этой связи внутригосударственное право перестает быть чисто национальным явлением. В.А. Карташкин справедливо отмечает, что ныне с полным основанием можно утверждать, что права человека являются предметом международно-правового регулирования и не входят уже исключительно во внутреннюю компетенцию государства ${ }^{10}$. Права человека регулируются как внутренним правом государств, так и международным правом. При этом все более возрастает роль международного права, что выражается, во-первых, во все более детальной разработке и конкретизации международных принципов и норм, регулирующих основные права и свободы человека, которые должны соблюдаться государствами, во-вторых, в создании международных органов по контролю за выполнением государствами взятых ими на себя обязательств" ${ }^{11}$ Термин «права человека» в данном случае употребляется только по отношению к тем правам, которые признаются и поддерживаются международным правом и его институтами.

Основы международного сотрудничества в данной области были заложены в Уставе ООН. В нем подчеркивается общий характер обязательства государств соблюдать основные права и свободы человека $^{12}$. Статья 1.3 Устава ООН в императивной форме обязывает все государства - члены ООН предпринимать совместные и самостоятельные действия в целях обеспечения всеобщего уважения и соблюдения прав человека и основных свобод для всех без различия расы, пола, языка и религии. Однако в Уставе не дано определения термина «права человека и основные свободы». Эта задача была выполнена в серии

${ }^{8}$ Мюллерсон Р.А. Права и свободы человека в международном праве. М., 1991. С. 8.

9. Карташкин В.А. Всеобшая демократия права человека в современном мире (к 40-й годовщине принятия Всеобшей декларации прав человека) // СЕМП, 1989. С.47.

${ }^{10}$ Сабо И. Идеологическая борьба и права человека. М., 1981. С. 111.

${ }^{11}$ Карташкин В.Н. Права человека в международном и внутригосударственном праве. М.,1995. С. 3.

${ }^{12}$ Международная защита прав человека. Основные проблемы сотрудничества государств. М., 1976. С. 21. 
деклараций, соглашений и договоров, составленных и принятых после 1948 г. Все документы по вопросам прав человека, принятые $\mathrm{OOH}$ и региональными организациями, исходят из одного и того же принципа - должны существовать единые стандарты прав человека, которые соблюдались бы всеми странами мира или, если речь идет о региональных документах, странами данного региона ${ }^{13}$. Все международные нормы в области прав человека, как договорные, так и обычные, стали именоваться в юридической терминологии международными стандартами.

Следует подчеркнуть, что права и свободы человека являются проявлением потребностей человека как такового, предопределяются условиями и характером развития конкретного государственноорганизованного общества и мировой цивилизации.

Права и свободы человека являются естественными, так как они, в конечном счете, не зависят ни от воли отдельных государств или даже групп государств, если речь идет о международных стандартах, ни от закономерностей общественного развития. Эти права и свободы должны быть обеспечены человеку. Государство обязано обеспечить каждому индивиду реализацию этих прав. Лишая их человека, оно действует противозаконно, даже если «узаконивает» в своем внутреннем законодательстве эти деяния, ибо его действия по отношению к человеку в данном случае соизмеряются не с его национальными законами, а с международными стандартами. Государство может лишать своих подданных или граждан многих прав, являющихся элементарными в других странах, но только незаконным образом ${ }^{14}$.

Определенные универсальные стандарты являются обязательными в рамках международного права. Принципы уважения и защиты прав и свобод человека были определены как jus cogens, т.e. как основополагающие императивные принципы международного права, действующие вне зависимости от позиции отдельных государств.

Всеобщая декларация прав человека и международные пакты содержат нормы, которые выделены из коллективного опыта и общего наследия всех народов мира и представляют собой универсальные стандарты поведения для всех народов и государств как выражение различных культур мира. Можно дать следующее общее для всех культур

1 Абдулалахи Ахмед Ан-Наими. На пути к исламской реформации гражданской свободы, прав человека и международного права: Перевод с англ., М., 1999. С. 182.

^ Мюлусрсон РА. Права и свободы человека в международиом праве. М., 1991. С. 5. 
обоснование всеобщности стандартов прав человека: это такие права, которыми каждое человеческое существо наделено уже просто по праву рождения, независимо от расы, пола, языка или религии. В этом смысле права и свободы человека предстают сами по себе как неотделимые, принадлежашие индивиду независимо от воли и желания данного государства.

Всеобщая Декларация прав человека 1948 г. и два международных пакта по правам человека стали важным этапом в развитии международных отношений. Как известно, Всеобщая декларация 1948 г. была принята в виде Резолюции Генеральной Ассамблеи. Тем не менее, при оценке юридической силы ее положений были высказаны разнообразные точки зрения. Ряд ученых считают, что она имеет лишь рекомендательный характер, другие утверждают, что ее положения имеют обязательную юридическую силу.

Декларация с формальной точки зрения не может рассматриваться как юридически обязательный документ. Тем не менее, провозглашенные в ней права и свободы рассматриваются в настояшее время государствами в качестве юридически обязательных норм международного права.

Всеобщая декларация прав человека сегодня является одним из основных источников права, служит моделью, которая широко используется многими странами для разработки отдельных положений конституций, различных законов и документов, относящихся к правам человека ${ }^{15}$. Не менее чем 90 национальных конституций, принятых после 1948 г., содержат перечень фундаментальных прав, которые или воспронзводят положения Декларации, или включают их под ее влиянием ${ }^{16}$.

Большинство государств рассматривают Декларацию как документ, содержащий общие нормы международного права, подавляющее большинство которых стали "jus cogens"17. Такое понимание особо важно в связи с тем, что ряд стран не являются участниками двух пактов: о гражданских и политических правах и об экономических, социальных и культурных правах. Они обязаны руководствоваться положениями Всеобщей декларации прав человека. Кро-

is Карташкин В.А. Россия и Всеобщая декларация прав человека // Московский журнал международного права. 1998. № 2. С. 244.

in Там же.

${ }^{17} \mathrm{CM}$. Mokean. W. Equality and discrimination under international law. - Oxford: Clarendon press.1982; United Nations actions in the field of human rights. N. Y., 1983. 
ме того, происходит конкретизация многих норм, содержащихся во Всеобщей декларации прав человека.

В итоге можно сказать, что все указанные документы и содержащиеся в них нормы и стандарты имеют двойственный характер: они являются обязательными для выполнения сторонами - участниками договорных норм и обязательными для всех государств в качестве обычных норм международного права.

Следует подчеркнуть, что существуют объективные факторы, определяющие сложность международного сотрудничества в области прав человека, а также обстоятельства, которые необходимо учитывать при формировании норм международного права в области прав человека. С одной стороны, это предполагает необходимость исходить из того, что существуют:

1) разное понимание, различный, иногда противоположный подход к самой концепции. Особенно сложную проблему представляют собой различия социально-экономического, политического характера, существующие между странами, участвуюшими в международной нормотворческой деятельности по правам человека и осуществлении принятых международньх норм. Целостное понятие не может быть выработано потому, что, во-первых, существуют различия в социальных условиях их существования; во-вторых, потому, что содержание и понятие прав человека меняются в ходе исторического развития;

2) глубокие различия в морально-правовьг воззрениях сторон на основе духовно-нравственных категорий, формирующих само понятие прав человека.

С другой стороны, необходимо принимать во внимание по крайней мере три уровня:

1) индивидуальный, относящийся к человеку как таковому;

2) общественный, определяемый условиями жизни данного государственноорганизованного общества, уровнем его развития, особенностями и традициями;

3) международный, определяемый характером и уровенем развития международных отношений и международного права, международных механизмов и процедур, т.е. характером человеческой цивилизации в целом.

Вопрос о международной правосубъектности в целом и в частности о статусе личности в международном праве, является одним из наиболее спорных вопросов в мировой юридической науке. Одни авторы 
отрицают правосубъектность индивида ${ }^{18}$, другие признают за ним отдельные качества субъекта международного права ${ }^{19}$.

Так, профессор Г.И. Тункин подчеркивал, что правовое положение индивидов определяется внутригосударственным, а не международным правом ${ }^{20}$. С.В. Крылов писал, что индивид защищается не непосредственно международным правом, а лишь через посредство внутригосударственного права, что постановления Устава ООН об основных свободах и правах человека, обязывая государства - члены организации, не сообщают индивидам качества непосредственно субъекта международного права ${ }^{21}$.

А. Федросс полагает, что отдельные лица в принципе не являются субъектами международного права, так как международное право защищает интересы индивидов, однако наделяет правами и обязанностями непосредственно не отдельных лиц, а лишь государство, гражданами которого они являются ${ }^{22}$. Данной точки зрения придерживаются и некоторые арабские авторы ${ }^{23}$. Другие считают, что индивид может быть лишь субъектом международных правоотношений. «Индивид, находясь под властью государства, не выступает на международной арене от своего имени, как субъект международного права, - пишет В.М. Шуршалов. - Все международные договоры и соглашения о защите личности, основных прав и свобод человека заключены государствами, а потому конкретные права и обязанности из этих соглашений вытекают для государств, а не для отдельных индивидов". Индивиды находятся под защитой своего государства, и те нормы международного права, которые направлены на охрану основных прав и свобод человека, главным

${ }^{18}$ См.,например: Тункин Г.П. Основы современного международного права: Изд. ВПШ. 1956. С. 19; он же: Теория международного права. М., 1970. С. 91, 259; Крылов С.В. История создания Организации Объединенных Наций. М., 1960, Федросс А. Международное право. М., 1959. С. 146; Хамед Султан Публичное международное право. 2-е изд. (на арабск. яз.). Каир, 1968. С. 86; Шуршалов В.М. Международное правоотношение М., 1971; Черниченко С.В. Теория международного права. В 2-х томах. М., 1999 и др.

${ }^{19} \mathrm{Cм.,} \mathrm{напрнмер:} \mathrm{Али} \mathrm{Садек} \mathrm{Абу-Гаиф.} \mathrm{Международное} \mathrm{публичное} \mathrm{право.} \mathrm{7-е} \mathrm{изд:} \mathrm{(на}$ арабск. яз.). Александрия, 1964-1965. С. 301; Вершетин В.С. , Мюллерссон Р.А. Приметы международного права в мировой политике // Сов. гос. и право 1989. № 5; Муромцев Г.И. Соотношение международного и внутригосударственного права в свете Конституции Российской Федерации // Право и политика современной России. М.

${ }^{20}$ Тункин Г.И. Основы современного международного права. М. 1956. С. 19.

${ }^{21}$ Крылов С.В. История создания Органивания Объединеннъх Наинй. М., МО. 1960. С. 34.

22 Федросс А. Международное право. М., 1959.С. 146. 
образом реализуются через посредство государства ${ }^{24}$. По его мнению, согласно действующим нормам международного права индивид выступает как субъект конкретных правовых отношений, хотя он не является субъектом международного права.

Противоречивую позицию в данном вопросе занимает английский ученый Я. Броунли. С одной стороны, он полагает, что существует общая норма, согласно которой физические лица не могут быть субъектами международного права, но в определенных контекстах индивид выступает как субъект права в международном плане. Однако, по мнению Я. Броунли, было бы бесполезно относить индивида к субъектам международного права, поскольку это предполагало бы наличие у него прав, которых в действительности не существует, и не избавляло бы от необходимости проводить различие между физическим лицом и иными субъектами международного права ${ }^{25}$.

Советская доктрина международного права традиционно отстаивала устаревшие концепции, в соответствии с которыми вопросы регулирования прав человека считались внутренним делом государства. Такая позиция диктовалась принципами тоталитарного режима, выступаюшего против принятия каких-либо радикальных мер на международном уровне, направленных на международную защиту прав человека. Подобные меры обычно квалифицировались как вмешательство во внутренние дела государства ${ }^{26}$.

Однако подавляющее большинство российских, европейских и арабских ученых в той или иной мере признают международную правосубъектность индивидов. Как справедпиво писал, например, английский юрист Латерпахт, международное право, как оно воплощено в Уставе ООН и других международных договорах, признает основные права индивидов независимо от внутреннего права государства и таким образом констатирует человека как субъекта международного права ${ }^{27}$.

Российские авторы «Курса международного права» относят индивида ко второй категории субъектов международного права. По их мнению, индивиды, обладая определенным, довольно ограниченным кругом прав

${ }_{23}^{23}$ Хамед Судтан. Публичное международное право во время мира. 2-е изд.(на арабск. яз.). Каир, 1968. С. 86; Шаваси Мухамед Башир Международное публичное право во время войны и мира. (на арабск. яз.). Александрия, 1971. С. 146.

${ }_{34}^{34}$ Шуршалов В.М. Указ. соч. М., 1971. С. 77.

2s Броунли Я Международное право. Перевод.с англ. Кн.1, М., 1977.С. 77.

${ }^{26}$ Общая теория прав человека М., 1996. С. 493.

${ }^{27}$ Lauterpacht $\mathrm{H}$. International law and Human rights. 
и обязанностей по международному праву, сами непосредственно не участвуют в процессе создания международного права ${ }^{28}$.

По мнению Н.В. Захаровой, отдельные нормы международного права применяются к индивидам. Она признает за ними международную правосубъектность ${ }^{29}$. Аналогичной точки зрения придерживается и арабский юрист Али Садек Абу - Гаиф ${ }^{30}$.

В настоящее время права и обязанности индивидов или государств по отношению к индивидам закреплены во многих международных договорах. Важнейшими из них являются Женевская конвенция об улучшении участи раненых и больных в действующей армии 1949 г., Женевская конвенция о защите мирного населения во время войны 1949 г., Устав международного военного трибунала 1945 г., Всеобщая декларация прав человека 1948 г., Конвенция о предупреждении преступления геноцида и наказании за него 1948 г., Дополнительная конвенция об упразднении рабства, работорговли и институтов и обычаев, сходных с рабством, 1956 г., Конвенция о политических правах женщин 1952 г., Международный пакт об экономических, социальных и культурных правах 1966 г., Международный пакт о гражданских и политических правах 1966 г., Конвенция против пыток и других жестоких, бесчеловечных или унижающих достоинство видов обращения и наказания 1984 г., Конвенция о правах ребенка 1989 г. Многочисленные конвенции одобрены МОТ.

Из региональных договоров отметим Европейскую конвенцию о защите прав человека и основных свобод 1950 г. и 11 протоколов к ней, Конвенцию СНГ о правах и основных свободах человека 1995 г. Аналогичные конвенции имеются и в других регионах мира. С одной стороны, в этих нормах, несомненно, говорится о правах индивндов, и это указывает на то, что именно они являются субъектами этих норм. С другой стороны, международные документы по правам человека прямо обязывают государства гарантировать индивидам эти права, а сами предусмотренные в них права обеспечиваются в отношении конкретного лица чаще всего не прямо, а посредством норм национального права и внутригосударственньх процедур, так как большинство этих

\footnotetext{
${ }^{28}$ Курс международного права. В 7-ми томах. Т. 1., М., 1989. С. 180.

${ }^{29}$ См.: Захарова Н.В. Индивид-субъект международного права. // Сов. Государство и право. 1989. № 11. С. 112-118.

${ }^{30}$ Али Садек Абу-Гаиф. Международное публичное право. 7-е изд. (на арабск. яз.). Александрия. 1964-1965. С. 301.
} 
норм являются несамоисполняющимися. Они сами по себе, непосредственно, без обеспечивающего их специального внутреннего законодательства не готовы к урегулированию вопросов соблюдения прав человека, даже если конституция государства объявляет их частью права страны. Однако если международная норма не может обеспечить закрепленные в ней права и свободы, она способна, в случае объявления ее действующей внутри государства, приостановить применение противоречаших ей правил внутригосударственного законодательства. Тем не менее, если нормы международного права в области прав человека обязывают государства обеспечить закрепленные в них права, то в то же время они представляют индивиду право требовать от государства выполнения его международных обязательств. Это закреплено, например, в ст. 20 Пакта о гражданских и политических правах.

К свойствам субъекта международного права можно отнести его ответственность за нарушение норм и принципов международного права. Ответственность несут как государства, так и индивиды. Индивид все более активно «вторгается» в международное право и даже в ряде случаев принимает участие в процессах обеспечения международных стандартов в области прав человека ${ }^{31}$. Единственным свойством, которым индивид не обладает, - считает профессор В.А. Карташкин, - это участие в создании принципов и прав.

Кроме того, государство, соглашаясь с международными нормами по правам человека, принимает на себя обязательства не только перед другими государствами и мировым сообществом, но и перед всеми лицами, находящимися под его юрисдикцией, - как гражданами, так и не гражданами.

Можно утверждать, что с принятием Устава ООН, Всеобщей декларации прав человека и пактов о правах человека 1966 г. индивид становится субъектом международного права. Например, в Пакте о гражданских и политических правах (ст. 16) зафиксировано, что каждый человек, где бы он ни находился, имеет право на признание его правосубъектности. Отсюда содержание правового статуса личности можно рассматривать с двух юридических позиций: права национального регулирования прав личности государством и права международного права коллективной защиты, права индивидуального обращения с жалобой в международные инстанции и права требовать защиты с их

\footnotetext{
${ }^{31}$ Карташкин В.А. Права человека в международном и внутригосударственном праве. C. 101 .
} 
стороны. Для защиты своих прав индивид может использовать закон государства, гражданином которого он является или где находится, или обратиться за помощью в международные органы. Непризнание индивида субъектом международного права означает недопустимость принятия каких-либо кардинальных норм на международном уровне, направленных на международную защиту прав человека. Тогда представляется, что именно государство, как официальный представитель гражданского общества в международньх отношениях, обеспечивает права человека, гражданином которого он является или на территории которого проживает.

После принятия Устава ООН широкое распространение получает практика предоставления индивиду права на прямой контакт с судебными и несудебными международными органами. Получая самостоятельный статус в международных органах, индивид имеет возможность независимо от государства зашишать свои права.

Индивид обладает международными правами и обязанностями, а также способностью обеспечивать (например, через международные судебные органы) выполнение субъектами международного права международно-правовых норм. Этого вполне достаточно для признания у индивида качеств субъекта международного права ${ }^{32}$.

Права человека, таким образом, становятся предметом международного регулирования. Международное сотрудничество государств по защите и реализации прав человека идет в следующих направлениях:

- создание норм и методов, определяющих процедуры, которые касаются ситуаций, затрагивающих интересы большого числа людей, т.е. систематических грубых нарушений прав человека и основных свобод. Это идет, как правило, по линии Пакта об экономических, социальных и культурных правах 1966 г., ЭКОСОС, Комитета ООН по правам человека, Подкомиссии по предупреждению дискриминации и защите меньшинства;

- закрепление норм и установление процедур, касающихся частных случаев. Это идет по линии Пакта о гражданских и политических правах и Факультативного протокола к нему, а также Комитета по правам человека;

- кроме того, в ООН и ее специализированных учреждениях существуют другие возможности для рассмотрения вопросов о нарушении 32 Международное публичное право: Учебник под ред. К.А. Бекяшева М:: Проспект, 1998. C. 114. 
прав человека. Все это значит, что права и свободы человека в значительной мере вышли за пределы исключительно внутренней компетенции государства, стали предметом международного регулирования. Развитие международных отношений и мировой цивилизации и соответствующие этому изменения в области международного права приводят к тому, что все большее количество вопросов, традиционно входящих в число внутренних дел государства, становится именно объектом международного права. Это значит также, что права человека уже не могут определяться исключительно характером и уровнем развития данного конкретного общества. Все большее влияние на их состояние оказывает единая человеческая цивилизация ${ }^{33}$. Следовательно, если защита прав и свобод человека осушествляется нормами внутригосударственного права, то содержательная сторона реализации регулирования в значительной мере уже не входит во внутреннюю компетенцию государства, поскольку последнее должно соблюдать свои международно-правовые обязательства в этой области.

Внутренняя компетенция как политико-правовая категория довольно подвижна. Она ограничивается в социально-политическом плане развитием международных отношений, которые характеризуются сегодня усилением интеграции и взаимозависимости государств. В юридическом плане объем внутренней компетенции зависит от развития международного права. Хотя в юридической науке отмечается, что те вопросы, которые регулируются международным правом, не являются делами ipso facto, входящими во внутреннюю компетенцию, это не значит, что все вопросы, возникающие в области прав человека, в полном объеме изъяты из внутренней компетенции. Многие вопросы регулирования прав человека все еще относятся к сфере внутренней компетенции каждого государства, которое самостоятельно, с учетом взятых на себя международных обязательств определяет время, последовательность и конкретный способ их выполнения. Эти вопросы решаются в зависимости от соотношения политических сил внутри страны, их позиции, а также от других факторов, а не только от существующих международных договоренностей. Все это отражается во внутригосударственном законодательстве, которое определяет, каким образом и в каком объеме государство будет выполнять взятые на себя международные обязательства ${ }^{34}$. Кроме того, международные

${ }^{33}$ Мюллерсон Р.А. Права и свободы человека в международном праве. М., 1991. С. 9. ${ }^{34}$ Карташкин B.A. Указ. соч. С. 10 
обязательства различных государств в одной и той же области не являются одинаковыми. Если общепризнанные обычные нормы по правам человека обязательны для всех государств, то иначе обстоит дело с конкретными договорными обязательствами. Они связывают только государства - участники конкретного договора.

Нет сомнения, что социально-экономическое и культурное развитие той или иной страны, а таюже стабильность и демократичность ее политической системы способствуют соблюдению и реализации норм и принципов международного права по правам человека. Но не менее важно создание международно-правовых механизмов и процедур реализации этих норм и принципов во внутригосударственной сфере. Целесообразно, на наш взгляд, и создание общемирового суда в этом плане. Создание такого органа гарантировало бы реализацию норм и принципов международного права в области прав человека при нарушении их со стороны государства. Поскольку права человека становятся проблемой всего мирового сообщества, то нарушение прав человека в отдельных странах надо рассматривать как нарушение международного права.

Следует подчеркнуть, что в условиях усиления взаимосвязанности и взаимозависимости равноправных государств комплекс прав и свобод человека может реализоваться только под воздействием международного права и при условии его примата.

Утверждение в международном праве принципа уважения прав человека вносит изменения в саму концепцию этого права. В прошлом она полностью была изолирована от топо, что происходилі внутри государства. Классическое международное право, рассматривая взаимоотношения между государствами и его собственными гражданами как входящие в его юрисдикцию, делало лишь одно исключение. Считалось правомерным применение силы в «гуманных» целях вплоть до развязывания войны в одностороннем порядке для защиты жизни и имушества, а также национальных и иных меньшинств. Право на гуманитарную интервенцию основывалось на предпосылке, что каждое государство якобы имеет международные обязательства гарантировать основные права и свободы, где бы они ни нарушались ${ }^{35}$.

Теоретическое обоснование подобных акций под предлогом «защиты» и «обеспечения» таких прав, как право на жизнь, на свободу совести и вероисповедания, получило освешение в трудах некоторых юристов. Исходя из того, что за абстрактным человеком, независимо от ${ }^{35}$ Права человека / Под ред. Е.А. Лукашевой. М.: Норма, 1999. С. 459. 
принадлежности его к тому или иному государству, признаются определенные права и свободы, Гуто Гроций оправдывал так называемые справедливые войны ради зашиты чужих подданных, если над ними творят «явное беззаконие» ${ }^{36}$. Дореволюционный русский юрист Ф. Мартенс писал, что все образованные государства признают за человеком как таковым, безотносительно к его подданству или национальности, известные основные права, которые неразрывно связаны с человеческой личностью ${ }^{37}$. Под этими правами обычно подразумевалось право на жизнь, свободу совести и вероисповедания. По утверждению швейцарского ученого И. Блюнчли, естественные права человека должны быть уважаемы как в мирное, так и в военное время ${ }^{38}$.

Точка зрения о законности вмешательства в дела других государств под предлогом гуманности нашла поддержку у большинства юристов как в XVIII, так и в XIX в. Лишь отдельные ученые, как, например, профессор А. Гефтер, утверждали, что если государство попирает права и свободы своих граждан, «то надо прекратить с ним всякие отношения, но не вмешиваться силой оружия в его внутреннее дело ${ }^{39}$.

Юристы - сторонники гуманитарной интервенции считали, что ее применение является правомерным только против нецивилизованных государств $^{40}$. «Вмешательство образованньх держав, - писал Ф. Мартенс - по принципу законно в том случае, когда христианское население тех земель подвергается варварскому гонению и избиению. В данном случае вмешательство оправдывает общность религиозных интересов и соображения человечности образованных народов с необразованными ${ }^{41}$.

Разделяя точку зрения о законности интервенции во имя «гуманных» целей, ряд ученьх, например, Ф. Лист, считали, что право на такую акцию возникает не в одностороннем порядке, а в результате решения группы государств, даже в случае, когда, по мнению отдельного государства, вмешательство во внутренние дела обосновывается необходимостью охраны общих интересов человечества ${ }^{42}$.

\footnotetext{
${ }^{36}$ См.: Гроций Гуго. О праве войны и мира. Три книги. М., 1956. С. 562-563.

${ }^{37}$ Мартенс $Ф$. Современное международное право цивилизованных народов. Т. 1. СПб., 1882. С. 327.

${ }^{38}$ Блюнчли И. Современное международное право цивилизованных государств, изложенное в виде кодекса. Вып. 2. М., 1877. С. 316.

${ }^{39}$ Гефтер А. Европейское международное право. СПб., 1880. С. 99.

${ }^{40}$ См.: Захаров Н.А. Курс общего международного права. 2 ч. М., 1917. С. 134.

${ }^{41}$ Мартенс Ф. У'каз.соч. С. 297-298.

42 Лист Ф. Международное право в систематическом изложении. Юрьев, 1917. С. 87.
} 
Доктрина гуманитарной интервенции широко использовалась в прошлом и используя в настоящее время в практике международных отношений ${ }^{43}$. Она служила одним из многочисленных обоснований для приобщения (нецивилизованных) слабых государств к цивилизации. Кроме того, во имя «гуманных» целей и под предлогом «защиты» национальных и религиозных меньшинств происходила борьба европейских держав за передел уже поделенного мира. Право на вмешательство официально закреплялось во многих международных договорах и соглашениях этого периода истории ${ }^{44}$. Однако как в XX в., так и ранее интервенция осуществлялась отнюдь не в гуманных целя ${ }^{45}$. Она исходила в основном из политических соображений, осуществлялась со стороны сильных и влиятельных государств на территории слабых государств и опиралась на силу, а не на правовые основания.

Исследуя внешнюю политическую деятельность и практику государств в XIX в., известный английский юрист Я Броунли приходил к выводу, что ни одна гуманитарная интервенция не совершалась и не совершается в гуманньх целях, за всеми подобного рода акаиями всегда стоит только политика. Во второй половине $\mathrm{XX}$ века большинство юристов согласилось с таким мнением" ${ }^{46}$."Подтверждением этому, например, - пишет один из крупных российских специалистов в данном вопросе В.А. Карташкин, - служжат действия США в Гренаде, Югославии и т.д. При этом США ссьллались как на имеющиеся договорные нормы, так и на обычные. Вместе с тем, следует обратить внимание на то, что созданный в 1970 г. Всемирной Ассоциацией международного права комитет по гуманитарной интервенции пришел к выводу, что гуманитарная интервенция («захват») в современньх условиях международных отношений применяться не должкна, поскольку ни обычньгх, ни договорньх норм, регулирующих механизм ее осуществления, нет. Таким образом, в настоящее время теория гуманитарной интервенции не пользуется поддержкой юристов большинства тосударств ${ }^{47}$.

${ }^{43}$ См.: Курс международного права в 7-ми томах. Т.2. М., 1989.

${ }^{44}$ См.: Общая теория прав человека. С. 420; Али Садек Абу-Гиев. Международное публичное право. М., С. 217.

${ }^{45}$ СM.: Bilder R.B. Kosovo and the "new interventionism" promise or peril? // j/of transnational law and policy - Tallahssene, 1999 - № 1. P. 153-182; Roberts A. Nato's "Humanitarian Way" over Kosovo// Survival - L. 1999 - Vol. 4.1.№ 3. P. 102-123. FaureDofourmantelle A. Irak et Kosovo // Defence national - P. 200.36. - P. 111-117.

${ }^{46}$ См.: Карташкин В.Н. Актуальные проблемы теории и практики международного гуманитарного права // Вестник МГУ. Серия Право. № 3. 2000. С. 112.

${ }^{47}$ См.: Карташкин. В.Н. Указ. соч. С. 217. 
В последнее время в российской юридической литературе встречается точка зрения, согласно которой государства вправе использовать вооруженные силы в случае зашиты свонх граждан за рубежом при угрозе их жизни. Такая акция рассматривается как крайнее средство, когда иные способы защиты не дают результата, а также в случае вооруженного нападения на граждан России ${ }^{48}$. Наиболее радикально по этому вопросу выступает Н.Б. Крылов. Прежде всего он ссылается на то, что еще в прошлом столетии практика межгосударственного общения привела к повсеместной защите государствами своих граждан за рубежом как способу самообороны. Более того, он напоминает о том, что в исключительных случаях допускалось применение вооруженной силы для оказания помощи гражданам друтого государства, правители которого творили вопиющее беззаконие и произвол ${ }^{49}$. Однако такое мнение отвергалось многими российскими авторами. В частности, известный российский юрист С.В. Черниченко, который более подробно анализирует данную точку зрения, приходит к верным, на наш взгляд, выводам, основываясь на удивительных аргументах ${ }^{50}$. Ссылки на необходимость защиты своих граждан неоднократно использовались для оправдания колониальных захватов и вооруженной интервенции с целью свержения неугодных правительств в прошлом, и, как показывает практика, под предлогом зашиты своих граждан сильные государства прибегали к военной интервенции и после второй мировой войны, только в отношении более слабых государств, которые обычно вовсе не разделяли их точку зрения на правомерность такой акции. «Просьба каких-либо государств, - отмечает С.В. Черниченко, - вторгнуться под любым предлогом на территорию их соседа не может быть ничем оправдана. Она есть нарушение прав человека соседней страны. В конце концов, и вооруженная защита своих граждан, чем бы ее ни обосновали - ссылками на самооборону или на правомерность гуманитарной интервенции - не всегда оказывалась результативной» ${ }^{51}$.

\footnotetext{
${ }^{48} \mathrm{Cм}$. Лукашук Г.И. Военная доктрина правового государства // Международная жизнь. 1994. № 3. С. 88.

${ }^{49}$ Крылов Н. Защита сограждан, находящихся в основном за рубежом // Международная жизнь. 1995 № 1. С. 124.

${ }^{\text {so }}$ См.: Черниченко С.В. Теория международного права. Т. 2. М., 1999. С. 449-476.

"І См.: Черниченко С.В. Теория международного права. С. 121. Старые и новые теоретические проблемы: В 2-х томах. Т. 2. М., 1999. С. 469.
} 
Кстати, в советской доктрине и практике долгое время господствовала точка зрения, согласно которой вооруженная защита своих граждан за рубежом считалась грубейшим нарушением международного права. Она нашла отражение в известном советском определении агрессии. В нем говорилось, что оправданием агрессии не может служить «опасность, могушая угрожать жизни или имушеству иностранцев». Эта же формулировка была воспроизведена в проекте резолюции Генеральной Ассамблеи ООН об определении агрессии, внесенном СССР в $1953 r_{.}^{52}$.

Несомненно, права человека - высшая ценность, и их защита - важнейшая, первейшая обязанность государства. Защита государством своих граждан есть защита самого государства, ведь народ - источник его суверенитета.

Государства вправе использовать такие институты, невооруженные и не связанные с нарушением прав человека, как реторсии и репрессалин. Государство может прибегать к таким мерам, помимо обращения в $\mathrm{OOH}$, если есть опасность массированного нападения на его граждан, или под угрозой находится жизнь небольшой группы граждан, или если уже пострадало какое-то небольшое число его граждан. Типичные случаи такого рода возникают, когда происходят захват заложников, внутренние беспорядки, гражданские войны и т.д. Каждая такая ситуация ставит перед государством, чьи граждане оказались в опасности, определенные задачи. Само собой разумеется, огромную роль играет здесь позиция и возможности властей государства, на территории которого возникла опасность или имеются жертвы среди граждан иностранных государств.

Судя по вполне отчетливой тенденции в современной практике, в тех случаях, когда в государстве происходят серьезные беспорядки или начинается война и появляется угроза жизни иностранньг граждан, находящихся на его территории, использование вооруженных сил для эвакуации своих граждан (или граждан других государств) считается правомерным, как это было, например, летом 1997 г. в Конго. Особенно ясной допустимость подобной акции становится в тех случаях, когда в стране возникает безвластие ${ }^{53}$.

Как правило, защита и своих, и чужих граждан с помощью военной силы раньше рассматривалась как гуманитарная интервенция, а не как

52 «Известия» от 26 августа 1953 r.

${ }^{33}$ См.: Черниченко С.В. Теория международного права. Старые и новые теоретические проблемы. В 2 томах. Т. 2. М., 1999. С. 465. 
самооборона. Периодически в ООН возникает вопрос о допустимости гуманитарной интервенции и в современных условиях. Ее рассматривают как средство защиты прав человека и обычно обсуждают только в связи с компетенцией Совета безопасности или региональных организаций, но в контексте прав на самооборону она обычно не затрагивается ${ }^{54}$.

Следует подчеркнуть, что между правами государств, народа, человека существует определенное единство. Все они должны осуществляться в соответствии с целями и принципами ООН. Нарушение прав государства во многих случаях означает и нарушение прав проживающих в нем людей. Прежде всего это касается таких кардинальных прав, как право на мир и право на жизнь. Совершая акт агрессии, правительства нарушают права не только других государств и их населения, но и права собственных граждан на мирную жизнь.

В общем, в межгосударственных отношениях использование вооруженных сил безусловно запрещено. Единственное исключение составляет право на индивидуальную самооборону в установленных для нее пределах. В этом состоит основа предусмотренного Уставом ООН и современным международным правом международного правопорядка. Каждое государство имеет право на индивидуальную самооборону в случае вооруженного нападения на него, что является актом агрессии. Это право в статье 51 Устава ОOH названо неотьемлемым, его реализация, в конечном счете, способствует восстановлению международного мира и безопасности.

Между тем, правопорядок, предусмотренный Уставом ООН и международным правом, оказался нереализованным. Сразу же после вступления в силу Устава ОOН началась «холодная война» и между постоянными членами Совета Безопасности. Недоверие и конфронтация наращивались гонкой вооружений. Принцип неприменения вооруженной силы в межтосударственных отношениях был подорван фактом ее применения одними государствами против других, в особенности государствами - постоянными членами Совета Безопасности ОOH в отношении государств, чья политика противоречила их интересам.

В настоящее время и после окончания холодной войны появилась тенденция, когда Совет Безопасности оказывается в стороне от усилий по поддержанию международного мира и безопасности. Случай

\footnotetext{
s4 TaM же.
} 
с Косово четко высветил тот факт, что государства и региональные организации иногда предпринимают принудительные акции без санкции $\mathrm{OOH}$.

Параллельно возникла тенденция нарушения международных санкций, введенных Советом Безопасности, отдельными государствамичленами и даже региональными организациями, кроме того, распространение региональных и субрегиональных соглашений ведет ко все большему размежеванию позиций в Совете Безопасности. Причем возникновение единственной сверхдержавы и новых региональных держав таюже внесло свою лепту в нынешнее положение в Совете Безопасности ООН.

Во время холодной войны, когда собственный потенциал ООН к принуждению был в значительной мере парализован расхождениями в Совете Безопасности, были случаи, когда грубейшие нарушения прав человека в одной стране приводили к военной интервенции одного из ее соседей. Так, в 1971 г. в результате интервенции Индии была остановлена гражданская война в Восточном Пакистане, что позволило Бангладеш добиться независимости. В 1978 г. Вьетнам осуществил интервенцию в Камбодже, положив конец правлению «красных кхмеров», развязавших геноцид. В 1979 г. Танзания осуществила интервенцию, чтобы свергнуть сумасбродную диктатуру Иди Мина в Уганде ${ }^{55}$. А после периода холодной войны - акции НАТО в Югославии.

Все эти случаи по-разному воспринимаются международным сообществом и вызывагот беспокойство. В каждом из них действия государств были односторонними или вне рамок $\mathrm{OOH}$, и это создает тревожный прецедент. Кроме того, такие действия осуществляются в силу заинтересованности государств в интервенции, в использования таких ситуаций для достижения определенных выгод в политическом плане, т.е. определяются приматом политики над международным правом.

Исторически сложилось так, что впервые вопрос о правах человека был вынесен на международный уровень религиозными и этническими меньшинствами. Нарушение их прав не раз было причиной дестабилизации обстановки не только в тех странах, где они проживают, но и вовлекало в конфликт другие страны. В наши дни нарушение прав меньшинств продолжает оставаться наиболее серьезной угрозой международному миру и безопасности.

ss Кофи А. Анан. Проблемы вмешательства. Выступление Генерального секретаря ООН. Нью-Йорк. 1999. С. 10-11. 
Озабоченность правами человека в мире обусловлена фактором взаимосвязи между правами человека и стабильностью в международных отношениях, сушествованием общих уз между различными народами, образующими международное сообщество. Этот фактор современного исторического развития не могут игнорировать страны мирового сообшества в своей внешней политике.

Характер международных отношений, взаимосвязь и взаимозависимость государств в современных условиях способствуют тенденции к исчезновению международных военных конфликтов и возникновению конфликтов, которые до недавнего времени считались внутригосударственными делами. В последние годы особенно возросло число такого рода вооруженных конфликтов в различных частях мира.

На первый взгляд, довольно просто разграничить международные конфликты, которые являются прямым делом ОOН, и внутренние споры, которые таковыми не являются ${ }^{56}$. Однако большинство войн в наше время - это гражданские войны. По крайней мере, такими они начинаются. Они являются «гражданскими» только в том смысле, что главной жертвой становится гражданское население ${ }^{57}$.

Кроме того, большинство конфликтов не остается "внутренними" длительное время. Они вскоре распространяются на соседние страны, Это может произойти, например, в том случае, если в ходе боевых операций войска той или иной из враждующих группировок окажутся на территории соседнего государства для перегруппировки и укрепления своих сил и откажутся разоружиться по требованию этого государства. Также это происходит, когда начинается поток беженцев. В связи с этим роль гуманитарного права приобрела особое значение. Возросла роль ООН в разрешении и предотвращении конфликтов, в установлении мира и стабильности. Совет Безопасности ООН стал оперировать такими понятиями, как угроза международному миру и безопасности в случаях, когда нарушения прав человека приобретают угрожаюший характер. В качестве примера можно привести действия Совета Безопасности в отношении Сомали, Гаити, Руанды. Более показательны

${ }^{56}$ См:. Алеш В.В. Правовое регулирование внутреннего конфликга немеждународного характера // Московский журнал международного права. 1998. № 2 С. 134; Ганюшкин Б.В. Вооруженные конфликты нового поколения // Материалы международной конференции «Вступая в XX век: к примату права международных отношений». Москва. 2 ноября. 2002.

${ }^{57}$ Кофи А. Анан. Проблемы Вмешательства. Выступление Генерального секретаря ООН. Нью-Йорк. 1999. С. 10-11. 
усилия по прекращению вооруженного конфликта в бывшей Югославии. Несмотря на все недостатки в их осушествлении, они сыграли важную роль. Без них количество человеческих жертв было бы гораздо большим. К сожалению, политика стран НАТО не дала ООН возможности реализовать свой потенциал, что привело к затягиванию конфликта. В той или иной стране было бы предпочтительно, если мировое сообщество прибегало бы к превентивным мерам и лишь в крайнем случае допускало вмешательство в военной форме во внутренние дела.

Гуманитарную интервенцию (вмешательство в гуманных целях) следует понимать, на наш взгляд, не только как использование вооруженных сил при эвакуации граждан с театра военных действий, а также из районов стихийных бедствий (или освобождения заложников с согласия данного государства), но также как прекращение конфликтов и разделение воюющих сторон, если это необходимо.

Гуманитарная интервенция должна осуществляться только со стороны ООН или международных региональных организаций с санкции $\mathrm{OOH}$.

Характер международных отношений в современном мире предполагает, на наш взгляд, необходимость изменения процедуры принятия решений, касаюшихся вопросов мира и безопасности. Принятие таких решений должно быть функцией не только Совета Безопасности, но и Генеральной Ассамблеи ООН, где такие решения должны приниматься большинством голосов. Целесообразно дать такой орган при принятии таких решений в указанных ситуациях права на вето или лишение права вето постоянных членов Совета Безопасности.

Одной из основных задач современности в области прав человека является, с одной стороны, дальнейшая конкретизация международных норм, закрепляющих права и свободы человека и предусматриваюших эффективные механизмы контроля за их соблюдением, а с другой стороны, обеспечение того, чтобы государства в договорном порядке признали их обязательность для себя. Государства берут на себя обязательства соблюдать исторически достигнутые стандарты прав человека, поскольку, в частности, от этого зависит и развитие межгосударственных отношений. Международное право учитывает важный аспект взаимосвязи внутренней и международной жизни государства.

Каждое государство обладает суверенной властью издавать нормы, определяющие права и обязанности своих граждан. Однако реализа- 
ция этих норм должна происходить в соответствии с международными стандартами.

В отличие от других принципов международного права, принцип уважения прав человека занимает центральное место в национальном праве. Ни одна норма права, как международного, так и внутригосударственного, не может ему противоречить.

Поддержание мира, обеспечение и защита прав человека - одна из главных целей $\mathrm{OOH}$. Существует взаимосвязь, с одной стороны, между состоянием мира и уровнем обеспечения прав человека, а с другой стороны - между правами человека и демократией (а также верховенства права), как внутри государства, так и между государствами.

Мировое сообщество постоянно убеждается в неразрывной связи между положением личности, ее правами и свободами в отдельных государствах и состоянием международных отношений. Наступает наиболее сложный этап социализации - это осознание человеком связи своих интересов с интересами всего человечества, понимание единства судеб всего населения земли. Государство должно осознавать свой статус члена международного сообщества и вытекающую из этого ответственность ${ }^{58}$.

Не только права человека, но и неразрывно связанные с ними вопросы демократии в целом, включая верховенство права, носят международный характер. Поскольку современное международное сообщество мыслит как демократическое, постольку социально-политические системы государств должны быть совместимы с их демократическими принципами. Становится ясно, что только демократическое государство способно быть полноценным членом международного сообщества. Любая страна может обеспечить себе нормальную жизнь только как полноправный член этого сообщества.

\footnotetext{
58 Лукашук И.И. Международно-правовая концепция России // Московский журнал международного права. № 2. 1998. С. 239.
} 